\title{
Claves y documentos para un Virgilio posmoderno: los años ochenta del siglo xx en España ${ }^{1}$
}

\section{Keys and Documents for a Postmodern Vergil: the 80s of the 20th Century in Spain}

\author{
Francisco GARCíA JURADO \\ https://orcid.org/0000-0002-3106-1178 \\ Universidad Complutense de Madrid, España \\ pacogj@ucm.es
}

\begin{abstract}
Resumen: Los años ochenta del siglo xx miraron a Virgilio con una visión precisa y propia, inspirada por Nietzsche, y que podría definirse, básicamente, por la idea de la muerte (Broch), la enfermedad de la poesía (García Calvo), la conmemoración del bimilenario de su muerte (Colinas), su relectura poética en la clave de nuevas estéticas (Borges y Bernhard), el auge de la traducción en verso (Fontán Barreiro) y, finalmente, la relectura visual de su Eneida (Carlos Franco). Este trabajo se propone, mediante el análisis de una colección de los documentos que ilustran tales aspectos, dar cuenta de cómo el decenio de los años ochenta ha configurado una imagen particular de Virgilio.

Palabras clave: Virgilio, Posmodernidad, España, Broch, García Calvo, Colinas, Borges, Bernhard, Fontán Barreiro, Carlos Franco
\end{abstract}

AвSTRACT: In the eighties of 20th century, Vergil was interpreted from a precise and particular approach inspired by Nietzsche. This new vision could be categorized, basically, as the idea of death (Broch), the sickness of poetry (García Calvo), the commemoration (remembrance) of the bimillennium of his death (Colinas), his poetic rereading from a new aesthetics (Borges and Bernhard), the boom of verse translation (Fontán Barreiro) and, finally, the remarkable picto-

\footnotetext{
${ }^{1}$ El presente trabajo se adscribe al proyecto de investigación "Diccionario Hispánico de la Tradición Clásica (DHTC)”. Proyecto FFI2017-83894-P. Quede constancia de mi agradecimiento a Hugo Bauzá, Antonio Colinas, Vicente Cristóbal López, Carlos García Gual, Antonio Guzmán Guerra, Jaime Siles y José Luis Vidal por haberme hecho partícipe de sus recuerdos. Vaya, asimismo, nuestro agradecimiento a Luis Arturo Guichard, que hizo posible un inolvidable y productivo encuentro con Antonio Colinas en la Universidad de Salamanca. A María José Barrios Castro debo agradecer, asimismo, su revisión del original.
} 
rial rereading of his Eneida (Carlos Franco). Therefore, this essay tries to give an account of a specific decade in Vergil's historical reception.

Keywords: Vergil, Posmodernism, Broch, Spain, García Calvo, Colinas, Borges, Bernhard, Fontán Barreiro, Carlos Franco

RECIBIDO: 16/09/2020 • ACEPTADO: 23/11/2020 • VERSIÓN FINAL: 04/12/2020

INTRODUCCIÓN: UN DECENIO PRODIGIOSO PERDIDO EN 2000 AÑOS DE TRADICIÓN LITERARIA

Es seguro que habrá lectores que se inicien en la lectura de este trabajo con sumo interés, si bien otros no podrán dejar de mostrarse, cuando menos, escépticos ante lo que en él se plantea. Acaso pocas cosas pueden parecer, en principio, tan divergentes como un poeta clásico de la altura de Virgilio y un decenio tan rompedor e iconoclasta como el de los años ochenta en España. Sin embargo, quien escribe estas páginas leyó y estudió por primera vez a Virgilio en aquella época y, al cabo de los años, ha ido cobrando conciencia de ciertas peculiaridades propias de ese momento que dieron lugar, asimismo, a una particular imagen del poeta. De esta forma, el autor de este ensayo, como parte que es de una generación concreta, se pregunta cuál ha sido (y es) "su Virgilio", es decir, aquel que le fue dado aprender desde las claves ideológicas y estéticas de la llamada "posmodernidad"2 en un lugar (España) y una época concreta (los años ochenta del siglo xx). El siglo $\mathrm{Xx}$, de manera particular, ha ido ofreciendo diferentes miradas acerca de Virgilio, desde los planteamientos estilísticos de los primeros decenios, pasando luego por las visiones características de los convulsos años treinta y cuarenta, o, en el caso de quien escribe estas líneas, durante aquel decenio de los ochenta. A lo largo del tiempo, autoridades como Haecker, Espinosa Pólit, Hernández Vista o García Calvo han ido imprimiendo una orientación diferente a los estudios virgilianos, ya fuera desde la actitud precristiana o adventista de los dos primeros, la estilística del tercero o la eminentemente personal y poética del cuarto. Si entendemos que la historiografía nos presenta una suerte de doble historia, la del autor como tal y la de las nuevas circunstancias donde se estudia, podemos observar cómo la lectura de Virgilio se ha ido viendo alterada a medida que el mundo también cambiaba.

\footnotetext{
2 Si bien aquí no podemos entrar en esta cuestión, partimos de la conciencia que sobre la posmodernidad como tal se generó a partir del influyente libro de Jean-François Lyotard titulado La condición posmoderna, publicado por primera vez en 1979 (Lyotard 1993).
} 
La indagación del presente ensayo ha surgido, singularmente, durante el año que estuvimos dedicados a escribir por encargo un libro para la editorial Síntesis: Virgilio: vida, mito e historia. ${ }^{3}$ Dentro de la inmensidad de los más de dos mil años de la historia de Virgilio, no nos pareció baladí considerar el peso específico que tuvieron los años ochenta del siglo $\mathrm{xx}$, aquellos que se corresponden con aquel fenómeno (contra)cultural que en España (y, de manera muy particular, en Madrid) vino a denominarse "la movida". En este sentido, un poeta coetáneo nuestro, Juan Antonio González Iglesias, nos sorprendió al comprobar que ciertos aspectos de su poema titulado "La canción del verano suena más que la Eneida" eran para nosotros reconocibles no tanto desde una dimensión meramente intelectual, sino básicamente vital, pues se trataba de elementos que sentimos como parte de una experiencia directa. Leamos, antes de nada, el poema:

"La canción del verano suena más que la Eneida"

$$
\text { para Jaime Siles }
$$

La canción del verano suena más que la Eneida y en vano -Cioran dice- busca Occidente una forma de agonía digna de su pasado.

Pero así están las cosas, y no tienen vuelta

ni las generaciones ni las hojas

de los hombres.

Tristeza de saber que no regresaremos a la ternura, la serenidad,

al fulgor de Virgilio.

Aquel verano

bailábamos oscuros bajo la noche sola. ${ }^{4}$

Emil Ciorán, filósofo del pesimismo, y el concepto de agonía de Occidente nos eran reconocibles desde una lectura clave de los años ochenta: $L a$ muerte de Virgilio, de Hermann Broch, cuya publicación en España tuvo lugar en 1979. De igual manera que somos capaces de reconocer a Homero gracias a la reelaboración de una de sus más conocidas comparaciones (la de las generaciones de los hombres con las hojas de los árboles), también podemos vislumbrar la sombra de Borges dentro de este poema, particular-

\footnotetext{
${ }^{3}$ García Jurado 2018.

${ }^{4}$ González-Iglesias 1997.
} 
mente en la expresión "el fulgor de Virgilio", donde aparece una palabra clave, "fulgor", que quienes vivimos aquellos años ochenta pudimos encontrar dentro de un relato recogido en el libro Los conjurados, el titulado "Las hojas del ciprés", donde el narrador se salva de la muerte en una pesadilla gracias al recuerdo de un verso de la primera bucólica. La dedicatoria a Jaime Siles, perteneciente a una generación de poetas y filólogos ampliamente leída durante aquel prodigioso decenio, no está reñida con el verso final, maravillosa paráfrasis del verso virgiliano que nos muestra la doble hipálage del descenso al infierno, y ambas cosas responden a una poesía culturalista, al tiempo que vital, que gozó de gran vigencia en los años referidos. El poema de González Iglesias está escrito a finales del siglo xx, ya transcurridos casi todos los años que conformaban el decenio de los noventa, pero esa distancia cronológica con respecto a los años ochenta marca todavía más, si cabe, la conciencia de una época que ahora vamos a intentar describir a partir de unos documentos esenciales.

Los años ochenta del siglo Xx se caracterizaron por un peligroso coqueteo entre el espectáculo y la alta cultura. Y decimos "peligroso" porque se trataba de una relación en la que el primero terminó devorando a la segunda. En lo que al mundo clásico se refiere, hemos heredado de aquel momento una visión alteracadémica y vitalista de los clásicos. El pensamiento de Nietzsche, según la relectura que de él hace el filósofo Gianni Vattimo, ${ }^{5}$ viene a fundamentar aquella visión de la Antigüedad. A este respecto, la representación teatral de los clásicos alcanzó una de sus cumbres durante los años ochenta, aunque en algunos montajes, a causa de lecturas muy personalistas, el autor antiguo no dejó de ser más que una mera excusa (véase, por ejemplo, la reseña de Eduardo Haro Tecglen acerca de un montaje teatral de Eurípides, titulada significativamente "Sobra Eurípides" ${ }^{6}$ ). De manera particular, Virgilio, como parte de esa alta cultura, experimentó cierta renovación espiritual y estética gracias a la celebración del bimilenario de su muerte (1981) y su consideración como "poeta neo-alejandrino", según veremos más adelante.

Es nuestro propósito repasar una serie de documentos esenciales que nos muestran a Virgilio tal como fue recreado y traducido durante aquella época. Si bien es comprometido llevar a cabo una mera delimitación cronológica entre dos años concretos, tales documentos nos permiten, asimismo, establecer objetivamente un período que discurre desde 1976 hasta 1992. De hecho, el ensayo sobre Virgilio de García Calvo fue publicado en 1976, aunque su impacto pleno tuvo lugar durante los años ochenta; por otra parte, la introducción de Vicente Cristóbal a la Eneida de Echave-Sustaeta, publicada

\footnotetext{
${ }^{5}$ Vattimo 2001.

${ }^{6}$ Haro Tecglen 1987.
} 
por la Biblioteca Clásica Gredos en 1992, ${ }^{7}$ ya incorpora en su propio relato una conciencia de lo acontecido a lo largo de este intervalo cronológico. Debemos tener en cuenta, asimismo, que algunos hechos relevantes, tales como la impronta virgiliana de Borges en los poetas españoles, transcienden con creces este período. Así las cosas, hemos logrado organizar nuestro estudio a partir de la reunión de una serie de documentos que atañen a la ficción literaria, el ensayo, el periodismo, la creación poética, la traducción y las artes plásticas. Esta es la relación de documentos que, a su vez, nos va a permitir organizar nuestro propio trabajo desde un punto de vista temático:

- La novela: Hermann Broch y su obra La muerte de Virgilio.

- El ensayo: el Virgilio de Agustín García Calvo.

- La conmemoración del bimilenario: recortes de prensa (diarios El País y $A B C$ ) y el "Canto X" de Antonio Colinas.

- La poesía: La cifra de Borges y Ave Virgilio de Thomas Bernhard.

- La traducción: la versión de la Eneida de Rafael Fontán Barreiro, entre otras.

- Las artes plásticas: el catálogo de la exposición sobre la Eneida de Carlos Franco.

Como puede verse ya en su mera enumeración, se trata de una serie de documentos heterogéneos cuyo único rasgo en común es la figura de Virgilio. Por otra parte, al ser estudiados con cierto detenimiento, ofrecen a menudo relaciones entre ellos que nos ayudan a entenderlos como una unidad orgánica. Debemos decir, asimismo, que no se trata de documentos que hayamos compilado a posteriori para llevar a cabo el presente estudio. Este conjunto de libros y recortes de prensa se fue configurando por sí solo a lo largo de aquellos años ochenta al calor de la mera curiosidad, aunque sin intuir todavía las claves culturales y estéticas que terminarían confiriendo unidad a aquel variopinto conjunto. Hoy tenemos la suficiente conciencia histórica como para ofrecer una lectura razonada de esta colección virgiliana. Vamos, por tanto, a desarrollar los diferentes aspectos que atañen al Virgilio de los años ochenta según la manera en que estos mismos documentos nos invitan a hacerlo.

\section{La muerte de Virgilio: Broch}

No es exagerado afirmar que el escritor austriaco Hermann Broch ha creado las bases conceptuales para lo que podemos considerar un Virgilio posmoderno. La versión española de su novela titulada La muerte de Virgilio

\footnotetext{
${ }^{7}$ Virgilio 1992.
} 
(publicada primero en lengua inglesa en 1945) había aparecido ya muy pronto en Argentina, en $1946,{ }^{8}$ si bien en España no lo hará hasta $1979,{ }^{9}$ en la editorial Alianza y a partir de la versión ya realizada en Argentina por Arístides Gregori. Si durante el bimilenario del nacimiento del poeta (1930), Theodor Haecker, con su Virgilio, padre de Occidente (1931), había sido el pensador más influyente de aquella generación en lo que a Virgilio respecta, la sombra de Broch se proyecta sobre el bimilenario de su muerte (1981). ${ }^{10}$

A la hora de analizar el cambio de perspectiva virgiliana a lo largo del siglo Xx, sería interesante comparar a Haecker con los nuevos planteamientos de Broch tras la segunda guerra mundial. Haecker todavía se encuentra dentro de los postulados del neohumanismo, donde pensadores como Werner Jaeger consideraban que la cultura clásica podía servir como modelo para cambiar el mundo. Broch, por su parte, muestra una actitud más cercana a la resistencia pasiva ante el poder de Augusto, hecho que dará lugar a la posibilidad de buscar una segunda lectura dentro de la Eneida.

Excelente intérprete del pensamiento de Broch en España es Jose Luis Vidal Pérez ${ }^{11}$ en torno a la fundamental pregunta relativa a los deseos que tuvo Virgilio de quemar su Eneida. Vidal abre la posibilidad de llevar a cabo una indagación virgiliana muy distinta con respecto al mero recurso positivista de utilizar las Vitae Vergilianae para recabar los datos de todas ellas y ponerlos en común. Como muestra Vidal, Broch recurre a un criterio que está en la base de la propia epistemología propuesta por Wilhelm Dilthey para el estudio de las humanidades: la aprehensión del objeto de estudio por parte del sujeto que lo investiga. ${ }^{12}$ De esta forma, Broch se pone en la piel de Virgilio, revive su propia circunstancia vital y descubre cómo el acto de terminar la Eneida, frente a las pretensiones de transcendencia que tiene para Augusto, implica algo muy distinto en el caso de Virgilio. Concluir la Eneida supone para Virgilio el fin de la creación poética y, por tanto, de su propia existencia. Así pues, desde los fundamentos de la moderna hermenéutica humanista, Broch cambió con su creación literaria la consideración acerca de Virgilio, incluso la académica, de lo que va a ser un buen ejemplo la llamada "Escuela de Harvard". Frente a los académicos europeos, los norteamericanos, como Adam Parry, se sintieron subyugados ante la posibi-

\footnotetext{
${ }^{8}$ Broch 1946.

${ }^{9}$ Broch 1979.

${ }^{10}$ Curiosamente, cuando Broch publica por primera vez su obra, en 1945, en España aparecía la versión española del libro de Haecker (Haecker 1945), en un contexto histórico y político ciertamente muy alejado del propio de la Europa de los años 30 .

${ }^{11}$ Vidal 1990 y 1992. Y en Argentina debemos hablar de Hugo Bauzá, especialmente en su novela Virgilio. Memorias de un poeta (Bauzá 2011).

12 Es lo que en otro lugar hemos denominado "Hermenéutica virgiliana” (García Jurado 2018, pp. 98-99).
} 
lidad de llevar a cabo una segunda lectura de la Eneida desde la resistencia pasiva al poder de Augusto. Broch es un ejemplo destacable a la hora de apreciar cómo lo alteracadémico puede terminar influyendo en el ámbito de la filología. No en vano, cuando Vattimo estudia el desplazamiento de Nietzsche desde la filología clásica a la filosofía, en una actitud que supone la crítica de la cultura y el historicismo, también contempla esta tensión que, con respecto al estricto mundo académico, producen aquellos análisis que llegan desde fuera de su ámbito para cambiar radicalmente el estado de las cosas. ${ }^{13}$ De esta forma, si es posible interpretar a Broch desde Nietzsche, cabe hacerlo de manera particular en torno a dos ámbitos:

- Un ámbito hermenéutico, a la manera de Dilthey, que implica "aprehender" al autor clásico (Virgilio) y convertir ese objeto de estudio en parte del sujeto que lo estudia (Broch), actitud que supone, asimismo, un rechazo al propio historicismo.

- Un ámbito alteracadémico que luego va a influir en una escuela concreta, la de Harvard, si bien la no aceptación de los presupuestos de esta escuela por parte del mundo académico europeo le sigue confiriendo cierto aire alternativo.

La repercusión de la obra de Broch va a ser notable en el panorama cultural español del decenio de los ochenta, donde el interés por la moderna narrativa germánica, desde Thomas Mann o Robert Musil hasta los narradores más modernos, como Heinrich Böll o Thomas Bernhard, se hace muy patente. Leído o, simplemente, conocido, Broch se convierte en un autor fundamental. A este respecto, es significativa la referencia a Broch que hace el escritor Pere Gimferrer en su ponencia titulada "El escritor de hoy y el mundo clásico" cuando se refiere a Virgilio en 1987:

[...] ¿qué nos dice la Eneida en verdad, fuera de su esplendor verbal indestructible? La pregunta no es ni baladí ni escolástica: en cierto modo, precisamente todo un libro capital de nuestro siglo, La muerte de Virgilio, de Hermann Broch [...] ha tratado de responder a ella. [...] En efecto, preguntar por el sentido actual de la Eneida es, en fin de cuentas, preguntar por el sentido no sólo de la tradición literaria, no sólo de la filología clásica, sino de toda la literatura y de toda la filología. La batalla contra la barbarie se libra precisamente en este terreno, y será reñida y decisiva. ${ }^{14}$

La muerte de Virgilio adquiere de esta forma nuevos valores simbólicos que van más allá de una simple muerte física, pues se trata, ante todo, de la

13 Vattimo 2001; recordemos que el libro de Vattimo se publica originariamente en italiano en 1985.

${ }^{14}$ Gimferrer 1996, pp. 154-155. 
muerte de la civilización y de la cultura frente a la barbarie. Esta circunstancia supuso, de hecho, una de las preocupaciones del momento, sobre todo cuando se produjo un drástico recorte de la enseñanza de las humanidades en la enseñanza media.

\section{La enfermedad de Virgilio: Agustín García Calvo (1976)}

El Virgilio de Agustín García Calvo aparece publicado en 1976, uno de los años clave de lo que conocemos como la "transición democrática" en España. Es entonces cuando García Calvo regresa a su cátedra de la Universidad de Madrid, de la que había sido expulsado, al igual que había ocurrido con Enrique Tierno Galván y José Luis Aranguren, dado que los tres participaron junto a los estudiantes en una manifestación estudiantil en 1965. De hecho, el libro fue elaborado en París, circunstancia a la que el profesor se refiere para disculpar ciertas dificultades a la hora de lograr bibliografía hispana reciente. ${ }^{15}$ Este ensayo sobre Virgilio, publicado en la Colección "Los Poetas" de la editorial Júcar, cambió la percepción del vate latino durante el siguiente decenio. Al igual que pudo ocurrir con el Catulo de Luis Antonio de Villena, ${ }^{16}$ igualmente publicado en la editorial Júcar, la percepción del antiguo poeta dio un importante giro en consonancia con el cambio político. García Calvo nos presenta, nada más comenzar su obra, a un Virgilio enfermo (no moribundo, como en el caso de Broch). Su enfermedad no es otra que la de la poesía. ${ }^{17}$ Se trata de un libro deslumbrante donde el poeta, ensayista y catedrático de filología latina desgrana sus profundos y personales conocimientos acerca de Virgilio y la propia creación poética. De manera significativa, se ofrecen traducciones rítmicas de algunos textos virgilianos, algo que va a influir en la tendencia posterior a traducirlo por medio de la imitación de sus ritmos. De esta forma, se crea la ilusión de que estamos leyendo al poeta en su lengua original. Cierto es que García Calvo se muestra muy escéptico ante este hecho, dados los contados lectores que quedan de Virgilio en los tiempos modernos, pero sus versiones nos permiten vislumbrar cómo podrían sonar aquellos versos latinos. Este es el ejemplo extraído de una de las bucólicas:

[...] va el mayoral también, los porqueros tardos vinieron: de la bellota iverniza [sic] llegó mojado Menalcas: todos “¿De dónde ese amor?” le preguntan. Apolo venía: "Galo.” le dice "¿a qué loquear?: tu tormento Licóride entre nevadas y rudos cuarteles se ha ido con otro [...]". ${ }^{18}$

\footnotetext{
15 García Calvo 1976, p. 102.

16 Villena 1979.

17 García Calvo 1976, p. 19.

18 Verg., Ecl., X, 19-23.
} 
[...] Lejos tú de tu tierra (¿que tenga yo que creerlo?) ves, dura tú, de los Alpes la nieve y del Rin las heladas sola sin mí. ¡Ah, no, no te hagan daño los fríos! $¡$ Ah, que tus tiernas plantas no hiera el áspero hielo! ${ }^{19}$

No parece que García Calvo hubiera leído a Broch, ni tampoco lo cita, si bien ambos autores se asemejan en sus apreciaciones acerca de un Virgilio que ejerce una suerte de resistencia pasiva ante Augusto. En cualquier caso, uno y otro se caracterizan por ofrecer poderosos retratos de Virgilio desde lo alteracadémico para terminar influyendo también entre los especialistas.

\section{El bimilenario de La muerte de Virgilio (1981): Antonio Colinas}

No es un hecho baladí para nuestro estudio que en 1981 se conmemorara el bimilenario de la muerte de Virgilio. Esta conmemoración tuvo un eco específico en Italia y, de manera notable, en la propia Ciudad del Vaticano, en cuya Biblioteca Apostólica se organizó una exposición virgiliana ${ }^{20}$ y donde hasta el mismo Papa Juan Pablo II pronunció un discurso sobre Virgilio en lengua latina. ${ }^{21} \mathrm{Si}$ bien de manera más discreta, el bimilenario también tuvo su eco en España, con celebraciones y actos en recuerdo del poeta. ${ }^{22}$ De entre aquellos actos, por la transcendencia que tuvo para el ámbito de la propia creación poética, debemos destacar el congreso celebrado en la madrileña Universidad Nacional de Educación a Distancia (UNED), que tuvo su discreto eco en los diarios El País y $A B C$. Es interesante hacer una lectura de tales reseñas, comenzando por la de El País, que aparece en la siguiente página. ${ }^{23}$

La breve crónica de El País nos relata cómo durante este congreso se celebraron varias sesiones acerca de diferentes aspectos más o menos relacionados con el poeta. Cabe destacar, especialmente, la sesión dedicada a las "Pervivencias de Virgilio en la poesía española", donde intervinieron, según la noticia, Antonio Colinas, Luis Alberto de Cuenca, Ignacio Gómez de Liaño, Jaime Siles y Luis Antonio de Villena. Cada uno aportó una visión diferente, al tiempo que complementaria, acerca del asunto. Finalmente, la semblanza que Villena escribe sobre Virgilio para completar la noticia nos permite apreciar una imagen de Virgilio muy influida por el propio retrato

${ }^{19}$ Verg., Ecl., X, 46-49.

20 Biblioteca Apostólica 1981.

${ }^{21}$ Arbea 2003.

22 Véase Oroz Reta 1982. En Argentina destaca el homenaje organizado por Hugo Bauzá, con un interesante libro que recoge diversos trabajos (Bauzá 1982).

${ }^{23}$ Villena 1981. 


\begin{tabular}{|c|c|c|c|}
\hline 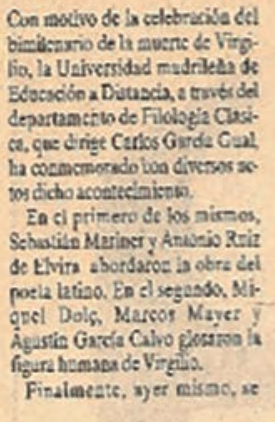 & 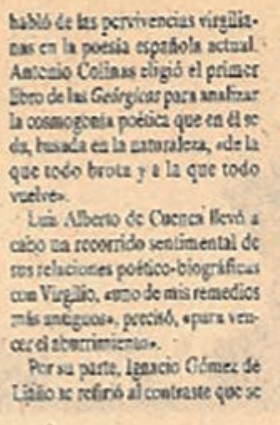 & 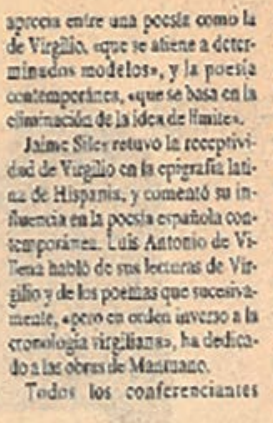 & 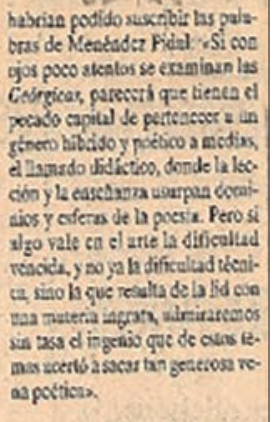 \\
\hline 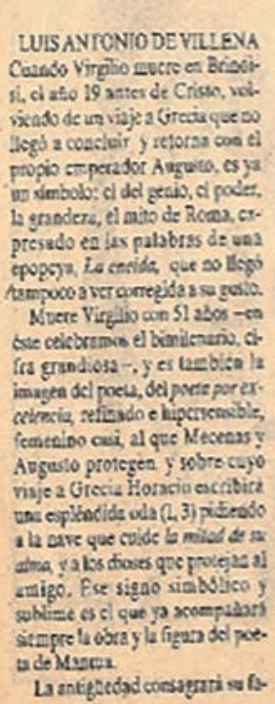 & 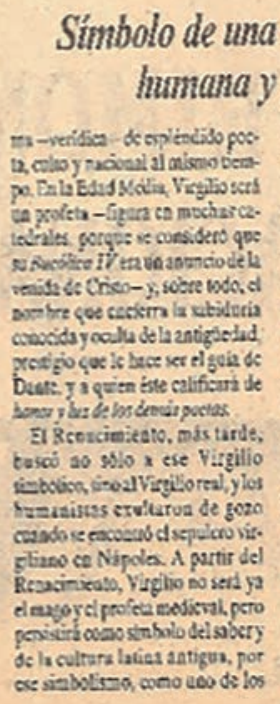 & 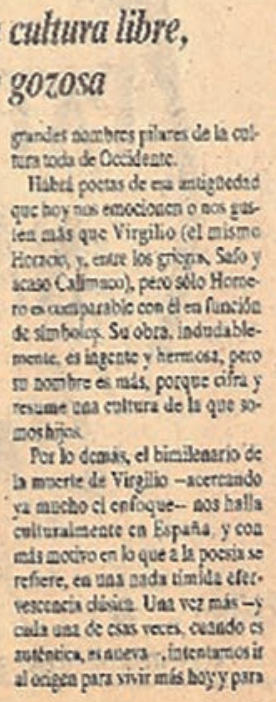 & 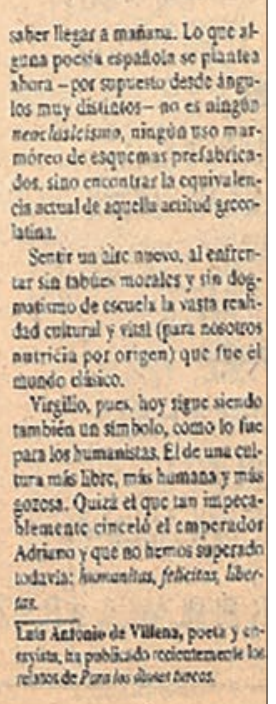 \\
\hline
\end{tabular}

Reseña del diario El País (28 de marzo de 1981) acerca de los actos conmemorativos del bimilenario del poeta Virgilio celebrados en la Universidad Nacional de Educación a Distancia.

que García Calvo había elaborado pocos años antes en su referido ensayo. ${ }^{24}$ Sin embargo, parece que algo no encaja bien en esta reseña. Nos referimos al hecho de que Jaime Siles hablase sobre epigrafía dentro del contexto de la pervivencia virgiliana en la poesía moderna. Conviene cotejar ahora lo ya leído con las informaciones dadas por el diario $A B C$. Se trata de dos noticias, una más general y otra más centrada en la mesa redonda sobre pervivencia. ${ }^{25}$ La primera de ellas es la siguiente:

\footnotetext{
${ }^{24}$ García Calvo 1976.

25 Anónimo 1981 y J.A.P.M. 1981.
} 
En un ciclo organizado por la Universidad a Distancia.

Virgilio: Conmemoración del bimilenario del gran poeta latino

MADRID. Como si se tratara de un descubrimiento arqueologico - al hilo del descubrimiento de la tumba de Filipo, el padre de Alejandro- los especialistas on historia y literatura clásicas se han puesto de acuerdo para fijar, casi por decreto, el bimilenario de la muerto de Virgilio, el poeta latino que mas corca se encuentra def profetismo de la poesia y la epica de hoy, acaso por concentrar en su obra rios actuales

Publio Virgilio Marón aparece y reaparece en la encrucjada de las díterentes epocas hace crisis o se encuentra en trance de cam. bio- que van desde el milenarismo del siglo I antes de Cristo al medieval y contern. poránco. Del fondo clásico de la poesía latina, de entre los Horac llega diuido a través liega dluido a traves Re la Edad Mecia, e el siglo XIX francés, como una conciencia de la historia y de la ilteratura.

VIRGILIO Y LA LITE. En el Rectorado de la Universidad NacioDistancia se iniciarán unas eConversaciones sobre Historia y Literatura Clásicas-.

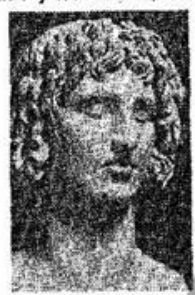

Virgilio

zadas por el Departamento de Filología Clá. sica de esta Universidad.

A partir de las diez de la mañana del A partir de las diez de la mañana de proximo lunes intervendran ios protesores Ro dríguez Adrados, Scharader y Garcia Gual, en torno al tema $\propto$ Mito, epica 1 historia en Grecia». En la segunda jornada, la del martes, sobre ef toma "La imagen de Alejan dro en la tradicion literarias, inlervendran los profesores Bravo, Guzman, Costas,

Se trata de una magn'fica amblentación Se trata de una magnitca an

A partir del miércoles las jornadas estarán A partir dei miercoles las jornadas estaran muerte dei gran poeta latino. En su primuerte del gran poeta latino intervendrán los profesores Marine. Rulz Elvira y Antonio Prieto Prieto, que habiaran sobre "La obsa iteraria de Virgilion. La sesion der jueves, 26, estara dedicada a "La figura de Yirgihon, con intervencion de Miguel Doç. M. Mayer ý Garcias Calvo. Finalmente, el viernes tinaizaran estas conversaciones Antonio Colinas, L. A. de Cuenca, gómez de Liaño y Luis Antonio de Villena, quienes planteatán el tema .Pervivencias virgilianas en ta poesia española actual

UNA LLAMADA DE FELICIDAD NATU RAL. Padre de Occidente, como le llamo Theodor Haecker, tutela una de las lecturas más frescas y lozanas de la vida del hombre. que conecta con el siempre vigente -menosprecio do corte y alabanza de aldeas, ai fin y al cabo hecho letra permanente on sus "Eglogas", "Georgicas", "Bucolicas" y hasta en la "Eneida. No es extrańo que las inquietudes mágicas y hasta esotericas de la poe sía europea actual de una parte y de otro, la reflexión ecologica, hagan recoger un men saje, cifrado en sus textos indeterminablos, de hace dos mul anos atrás. Virgilo, mitificado - puro, profético o simplemente natural - existe un concepto de lo virgitiano como una lamada a la vida en paz, a la vida sose gada que llovaria más tarde fray Luis de Leon

incorporado a la tradición itteraria occidental y sobre ella ha llegado a nosotros, dosde Ovi. dio a Séneca, desde Silio Itálico a Estacio, desde Petrarca a Ariosto y desde Dante Torcuato Tasso

Virgilio inspiró en la Edad Media la poesía alegórica. Es posible olvidar la magnificación que se hizo a lo largo del tiompo de su famosa a Egloga IV un precursor y un profeta del cristianismo al anunciar un worden nuevo- y una enveva edad. considerada como una protecla del nacimiento de Cristo. Toda la poesía pastoral y didáctica del Renacimiento arranca de una exégesis apasionada de las "Bucolicas" y de las "Geórgicass, Y ni siquiera el subjetivismo exaltado del romanticismo, que quiso sustitur el mundo romano por el griego, pudo deteriorar la imagen del delicado poeta, al que Dante considero corno el máximo símbolo de

HOMBRE Y POETA DE SU TIEMPO. De Virglio hay muchas facetas que aplicar al desnortado mundo contemporáneo. Y no es la menos importante la que lo encarna en una significacion humana $Y$ en uno contextos so. clopoíiticos. El poeta de Mantua, amigo de Augusto. pone en sus vorsos una intonconalidad polifica. Canta al campo para que el puoblo romano vuelva a la vida sencila -obje. tivo que comparte con Horacio - y a los placeres campesinos. Es uno de los ciasicos más leídos. Su mesianismo ha ayudado durante muchos siglos a su leyenda, pero hoy es et sentimiento nacional y el culto al heroismo, la profundidad del dolor humano, el afan de fraternidad humana, to que le hace estar vivo y reflexivo, tal y como Hermann Broch to presenta, patético poco antes de su tallecimiento, en aLa muerte de Virgiliow.

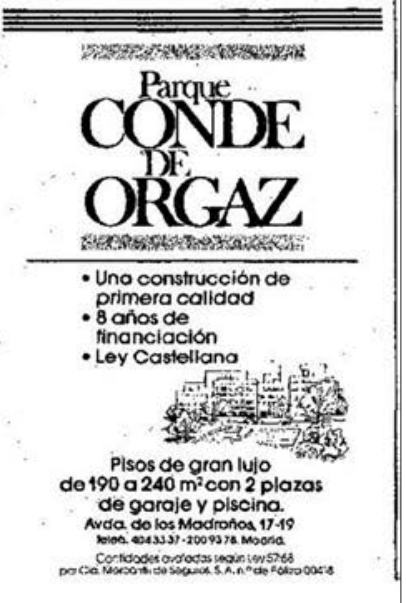

Reseña del diario $A B C$ (21 de marzo de 1981) sobre el congreso conmemorativo del poeta Virgilio celebrado en la Universidad Nacional de Educación a Distancia. 
De manera significativa, podemos ver en esta reseña la referencia a los dos autores capitales que han escrito acerca de Virgilio en el siglo xx: Haecker y Broch, el primero por considerar al poeta "padre de Occidente" y el segundo por la profundidad que ve en Virgilio acerca del dolor humano y el afán de fraternidad. Asimismo, en el mismo diario podemos encontrar otra reseña firmada por J.A.P.M., relativa ya a la mesa redonda acerca de las "Pervivencias virgilianas en la poesía española actual" donde, según la información que se nos da, intervinieron cuatro personas y no cinco. Este hecho explica probablemente la disonancia ya referida, pues Siles intervino en otra sesión diferente. Es oportuno pasar a leer el resumen acerca de lo que se trató en aquella mesa redonda:

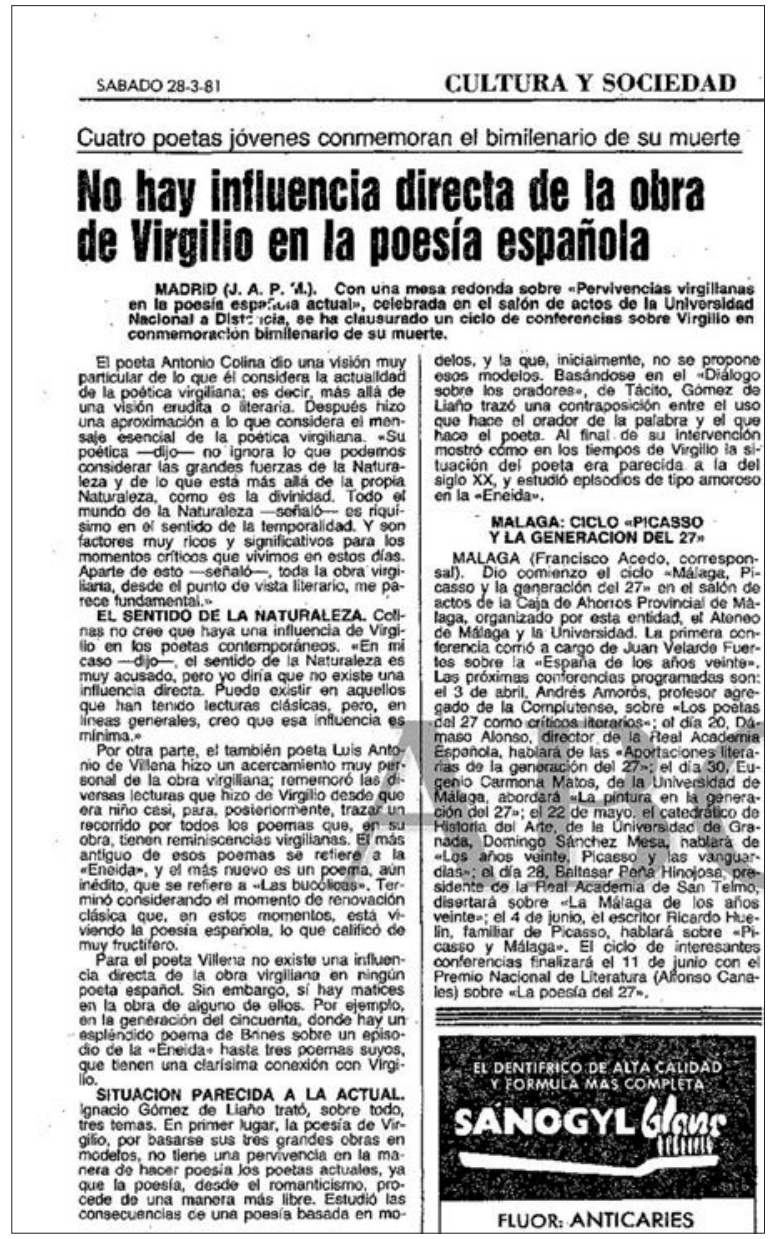

Reseña del diario $A B C$ (28 de marzo de 1981) acerca de la mesa redonda sobre las "Pervivencias Virgilianas". 
En la reseña de $A B C$, si bien se afirma que intervinieron cuatro personas, se olvida luego mencionar a Luis Alberto de Cuenca. Resulta significativa, en cualquier caso, la constatación, por parte de los intervinientes (salvo en el caso de Luis Antonio de Villena en lo que respecta a su propia obra) de que no haya "influencia directa" de Virgilio en la moderna poesía española. En este caso, convendría reflexionar un poco acerca de lo que se quiere decir mediante la expresión "influencia directa", acaso relativa a un "virgilianismo" que, ciertamente, ya no tendría lugar de ser en un momento como el final del siglo xx. Sin embargo, sí cabe hablar de una activa recepción virgiliana basada en la recreación moderna de algunas de sus más importantes figuras retóricas (por ejemplo, las hipálages) e imágenes poéticas. Afirmar, en definitiva, que no existe una influencia directa no implica que Virgilio deje de estar presente en la poesía moderna. En este sentido, resulta destacable la intervención de Antonio Colinas acerca de Virgilio por medio del tema de la naturaleza, dado que no resulta un asunto ajeno a la propia obra de Colinas. ${ }^{26}$ Afortunadamente, disponemos del texto de su conferencia, donde trató, de forma concreta, acerca del libro I de las Geórgicas ("Cosmogonía del libro I de las Geórgicas" 27 ), texto que proviene del que había leído en la misma mesa redonda de la UNED y que apareció primeramente publicado en la revista Ínsula en septiembre de 1981, si bien con otro título ("Lección primera y última de Virgilio"28). Pero lo que sin duda parece el fruto más perenne de aquellos actos fue el poema de Colinas sobre la muerte de Virgilio publicado en su libro titulado Noche más allá de la noche. ${ }^{29}$ Se trata de un poema claramente deudor de la Muerte de Virgilio de Broch, pero también de la propia idea que el poeta tiene acerca de la naturaleza, dentro de lo que resulta ser una constante en la obra de Colinas: el Sur, representado por Bríndisi, y el Norte de la Península Ibérica. ${ }^{30}$ Colinas traslada a los pasajes remotos del Bierzo el asunto de la muerte de un soldado romano que agoniza al mismo tiempo que Virgilio lo hace en Bríndisi. El soldado pide que graben en su tumba un verso del poeta: ${ }^{31}$

\footnotetext{
${ }^{26}$ Herrero Tabernero 2007; este autor ha estudiado presencias de las Geórgicas en uno de sus poemarios.

${ }^{27}$ Colinas 1989, pp. 67-73.

${ }^{28}$ Colinas 1981.

${ }^{29}$ Colinas 1982.

${ }^{30}$ Huerta Calvo 1997, pp. 208-219.

${ }^{31}$ Como el mismo Colinas nos refirió en Salamanca, durante la mesa redonda en torno a su poesía y los clásicos, organizada por Luis Arturo Guichard (Salamanca, 4 de abril de 2019), tuvo como motivo de inspiración la noticia del hallazgo de una inscripción latina en El Bierzo.
} 
"Canto X"

Mientras Virgilio muere en Bríndisi no sabe que en el norte de Hispania alguien manda grabar en piedra un verso suyo esperando la muerte. Este es un legionario que, en un alba nevada, ve alzarse un sol de hierro entre los encinares. Sopla un cierzo que apesta a carne corrompida, a cuerno requemado, a humeantes escorias de oro en las que escarban con sus lanzas los bárbaros. Un silencio más blanco que la nieve, el aliento helado de las bocas de los caballos muertos, caen sobre su esqueleto como petrificado.

Oh dioses, qué locura me trajo hasta estos montes a morir y qué inútil mi escudo y mi espada contra este amanecer de hogueras y de lobos. En la villa de Cumas un aroma de azahar madurará en la boca de una noche azulada y mis seres queridos pisarán ya la yerba segada o nadarán en playas con estrellas. Sueña el sur el soldado y, en el sur, el poeta sueña un sur más lejano; mas ambos sólo sueñan en brazos de la muerte la vida que soñaron. No quiero que me entierren bajo un cielo de lodo, que estas sierras tan hoscas calcinen mi memoria. Oh dioses, cómo odio la guerra mientras siento gotear en la nieve mi sangre enamorada.

Al fin cae la cabeza hacia un lado y sus ojos se clavan en los ojos de otro herido que escucha:

Grabad sobre mi tumba un verso de Virgilio. ${ }^{32}$

Dentro de la complejidad del poema y de sus símbolos, queremos destacar la imagen expresada por el verso "un silencio más blanco que la nieve", hipálage, sinestesia y comparación a un tiempo que recuerda al famoso verso de Carducci "il divino del pian silenzio verde" que cierra su poema "Il bove", 33 creado con el trasfondo virgiliano del bucolismo y de hipálages como "los amistosos silencios de la luna", a la que volveremos más adelante. Por lo demás, la nieve es un símbolo clave en la poesía de Colinas que podemos reencontrar en metáforas ya propias de su poesía posterior, como ocurre indirectamente con la expresión de "el crujido de la luz", que

\footnotetext{
32 Colinas 1982, pp. 263-264. Reproducimos aquí la versión primera del poema, correspondiente a la edición de 1981, no la que el poeta ha ido retocando a lo largo de los años.

${ }^{33}$ Carducci 1887, p. 17.
} 
representa, como el mismo poeta declara, una imagen de infancia, cuando, tras una intensa nevada, experimentó el ruido que la nieve produce al ser pisada. $^{34}$

Nostalgia y ausencia de Virgilio: Jorge Luis Borges (1981-1986) Y THOMAS BERNHARD (1981)

En la mesa redonda acerca de la pervivencia de Virgilio en la poesía española se había concluido que no existía una influencia directa del antiguo vate sobre los nuevos poetas españoles. Quizá se estuviera pensando en esquemas muy clasicistas, a la manera de lo que podía ocurrir en los tiempos de Garcilaso (o de la poesía garcilasista, más cercana en el tiempo y cultivada por autores como José García Nieto), sin que se tuviera in mente una concepción más amplia de la propia recepción virgiliana. Sin embargo, ya en la adecuada distancia temporal, cabe aportar a este debate dos aspectos relativos a sendos autores modernos:

- La renovada lectura virgiliana de Borges, que era ya una realidad en aquellos tiempos (y alcanza, acaso, su cumbre, en Los conjurados), pero quizá no tanto la aceptación de Borges dentro del canon de la poesía escrita en lengua española y, mucho menos, como un autor clave para la moderna recepción hispana de los clásicos.

- No se menciona tampoco a Thomas Bernhard, cuyo poemario Ave Virgilio, compuesto varios años antes, acababa de ser publicado en 1981, aunque no llegará a haber una versión española hasta muy entrado el decenio de los años ochenta.

Merece la pena echar un vistazo a estos dos autores pertenecientes, más allá de sus orígenes, a la literatura mundial. Recordemos que Borges había recibido el premio Cervantes de literatura, junto con Gerardo Diego, en 1979. En el año de 1976 ya había sido entrevistado para RTVE por Joaquín Soler Serrano en su mítico programa "A fondo", entrevista a la que luego siguió otra en 1980. Asimismo, el libro de literatura española de Vicente Tusón y Lázaro Carreter para el Curso de Orientación Universitaria ${ }^{35}$ sirvió de elemento clave para esta canonización a lo largo de los años ochenta, ${ }^{36}$ por

\footnotetext{
${ }^{34}$ Colinas 2004.

35 Tusón y Carreter 1983.

36 Debo esta feliz idea a mi colega y amigo Pedro Conde Parrado, de la Universidad de Valladolid.
} 
lo que esta conciencia borgiana es ya propia de los jóvenes que estudiaron literatura a lo largo de aquel decenio y de los poetas que luego comenzaron a producir su propia obra durante los años noventa. A pesar de su peso específico y de su transcendencia, el reconocimiento de la relación de Borges con Virgilio ha sido tardío. De manera excepcional, Miguel D’Ors ya había observado en 1976 las afinidades virgilianas de Borges en lo que respecta a construcciones como el célebre "lento en mi sombra", que encontramos en el "Poema de los dones", y que nos llevaría hasta el lentus in umbra del comienzo de la primera Bucólica de Virgilio. ${ }^{37}$ La poesía de Borges y, muy en especial, la publicada durante la primera mitad de los años ochenta hasta su muerte, se va a caracterizar por la nostalgia de Virgilio y la impronta que tiene en el propio Borges la llamada "estética de la expresión" de Benedetto Croce, que invita a considerar las figuras retóricas como puras imágenes poéticas. Estamos hablando, básicamente, del Virgilio que puede vislumbrarse tanto en La cifra como en Los conjurados. La cifra ${ }^{38}$ se abre con un pequeño texto, titulado "Inscripción", que termina de esta forma:

Cuántas mañanas, cuántos mares, cuántos jardines del Oriente y del Occidente, cuánto Virgilio. ${ }^{39}$

Y el mismo libro se cierra con un poema cuyo título coincide con el del mismo poemario, "La cifra", y que comienza de esta manera:

La amistad silenciosa de la luna

(cito mal a Virgilio) te acompaña [...]. ${ }^{40}$

Este poema reelabora parte de un precioso verso virgiliano que, por cierto, también había dado título a un libro del poeta irlandés William Butler Yeats: Per amica silentia lunae, publicado en $1917 .{ }^{41}$ Recordemos el contexto del verso virgiliano. Los griegos, tras haber hecho creer que abandonaban Troya, se ocultaron en la isla de Ténedos y, desde allí, regresaron al anochecer gracias a la luz incierta de la luna:

Et iam Argiva phalanx instructis navibus ibat

a Tenedo tacitae per amica silentia lunae

litora nota petens. ${ }^{42}$

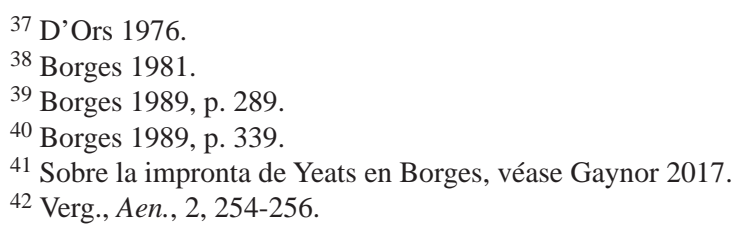


Y ya la falange argiva se desplazaba con sus naves en orden desde Ténedos, por entre los silencios amistosos de la tácita luna, en busca de las playas conocidas. ${ }^{43}$

Esta lectura virgiliana se irá diseminando en la propia poesía de Borges a lo largo de toda su vida, pero muy especialmente en su última producción. La obra ya citada, La cifra, y Los conjurados son espléndidos ejemplos de esta presencia de las imágenes virgilianas. Pero donde Borges rinde su gran homenaje al poeta latino es en su prólogo a la Eneida de Virgilio, dentro de la colección "Biblioteca Personal". En este texto Borges logra compendiar su conocimiento acerca del poeta: ${ }^{44}$

Diecisiete siglos duró en Europa la primacía de Virgilio; el movimiento romántico lo negó y casi lo borró. Ahora lo perjudica nuestra costumbre de leer los libros en función de la historia, no de la estética (Borges, Prólogo a La Eneida, en "Biblioteca Personal"). ${ }^{45}$

En el mismo prólogo regresa también a los versos ya citados del libro segundo de la Eneida:

Virgilio no nos dice que los aqueos aprovecharon los intervalos de oscuridad para entrar en Troya, habla de los amistosos silencios de la luna (Borges, Prólogo a $L a$ Eneida, en "Biblioteca Personal"). ${ }^{46}$

Carlos Mariscal de Gante ha dedicado interesantes páginas a indagar acerca de la productividad poética de la hipálage virgiliana ${ }^{47}$ en uno de los traductores hispanoamericanos más destacados de Virgilio, el ecuatoriano Espinosa Pólit, así como en el mismo Borges y el poeta mexicano José Emilio Pacheco. ${ }^{48}$ En definitiva, se ha creado una nueva convención poética a partir de la renovada lectura de la Eneida.

Por su parte, Thomas Bernhard con su Ave Virgilio deja ver, sobre todo, lo que podría considerarse, de manera paradójica, como un "infierno

43 Trad. García Jurado.

44 García Jurado 2010 y Nogales-Baena 2017.

45 Borges 1996, p. 521.

46 Borges 1996, p. 521.

${ }^{47}$ Acerca de la hipálage o enálage apunta Gian Carlo Conte: "The most powerful of these effects are obtained by means of the simplest figures. Nothing is more simple and at the same time more effective than enallage (or, if one prefers, hypallage), that is, the trope which exchanges the syntactic relations among words: one element of the phrase, often the adjective, is referred not to the element to which it belongs by a logical or grammatical connection, but to another one more or less near by” (Conte 2004, p. 70).

${ }^{48}$ Mariscal de Gante Centeno 2020. 
bucólico". ${ }^{49}$ El latinista Von Albrecht se refiere al Ave Virgilio (1981) en estos significativos términos:

De Virgilio (y, al mismo tiempo, de la literatura moderna con raíces clásicas) se distancia, como era de esperar, Thomas Bernhard (Ave Vergil, compuesto en 19591960, impreso en 1981). ${ }^{50}$

Es notable en el texto del profesor Von Albrecht no solamente su natural y esperable conocimiento del escritor Thomas Bernhard, figura clave de las modernas letras austriacas, sino ese comentario, "como era de esperar", referido al alejamiento de este poemario con respeto a lo que podemos considerar como la "tradición clásica". Thomas Bernhard no es un escritor al uso, tanto en su incipiente faceta poética como en lo que luego ha constituido el desarrollo principal de su literatura: la novela y el teatro. En lo que respecta a su poemario Ave Virgilio, ciertamente, el lector no debe esperar encontrarse ante una suerte de poesía con raíces virgilianas. Es la impronta del poeta T. S. Eliot, más en concreto la de su obra The Waste Land, la que deja adivinarse en los versos descarnados y sombríos de Bernhard. El propio contenido y formulación de los títulos que articulan el poema ("Los invitados a la boda", "Mañana de invierno", "Duelo", "Tu muerte no es mi muerte", "Octubre", "Quién en esta ciudad" y "Conmigo y con mi país") recuerda ya, asimismo, a T. S. Eliot. Esta moderna tradición eliotiana, sin embargo, no es ajena ni a la obra ni tampoco a la figura de Virgilio, como bien saben quienes han leído los ensayos de T. S. Eliot acerca del poeta de Mantua y su carácter clásico. Por lo demás, The Waste Land guarda profundas conexiones con la propia Eneida, como podemos ver en un artículo ya clásico de Marjorie Donker. ${ }^{51}$ Por tanto, esta suerte de alejamiento de la obra de Bernhard de lo que consideramos la tradición clásica a través de T.

49 “Composto verso il 1960, pubblicato nel 1981, e definito dallo stesso Thomas Bernhard come un testo di assoluta pregnanza all'interno della sua produzione narrativa, Ave Virgilio rappresenta l'esito di due tendenze stilistiche apparentemente contraddittorie. Riflessione teorica e concrezione corporea, teologia negativa e ossessione materica, proiezione simbolica e décor regionalistico convergono nella stesura di un manufatto nero ed oracolare. Infatti, benché il libro rechi le tracce di due soggiorni all'estero (Gran Bretagna e Italia), il suo vero cuore sta nel lacerante sentimento di attrazione e odio che l'autore nutre verso la propria terra. [...] Osti, parroci, sindaci, mastri birrai, arcivescovi, scrivani comunali, contadini e sposi, figure dell'autorità o del martirio (il Padre contro il Figlio) insieme a baluginanti santi intercessori quali Catullo, Dante, Pascal o Virgilio, compongono il quadro di un inferno bucolico fatto di sangue, cunei nella carne, mattatoi. [...] Profeta dei deformi, l'io narrante erige il suo carme sulle fondamenta della prosa, tra nomi e contronomi. Così, la sua voce del lutto attraversa la realtà creaturale in tutto il suo orrore, fino a produrre un'esperienza poetica tra le più originali e convulse del secondo Novecento" (Magrelli 2017).

${ }^{50}$ Von Albrecht 2012, p. 195.

${ }^{51}$ Donker 1974. 
S. Eliot no dejaría de constituir una suerte de curiosa paradoja. En cualquier caso, el lirismo desolado de Bernhard y los paisajes devastados donde se inscriben sus poemas ofrecen claramente esta impronta tan característica de la poesía moderna. La escritura de este poemario tuvo lugar en Oxford y en la siciliana localidad de Taormina, según declara el autor en la nota que aparece al final de su libro. Quizá sea el origen campesino de Bernhard lo que lo acerque sentimentalmente al poeta latino, a quien Bernhard parece buscar con insistencia desde el comienzo de la obra.

Ave Virgilio es un poemario escrito entre 1959 y 1960, si bien no apareció publicado hasta 1981, no sabemos si en un intento de hacer coincidir la edición con el bimilenario de la muerte de Virgilio. En España, el poemario no vio la luz hasta 1989, en versión de Manuel Sáenz. ${ }^{52}$ Vayamos al inicio del poema titulado "Mañana en invierno". Allí encontramos un tono de invocación ya desde los dos primeros versos:

No es que sea incapaz

de pronunciar tu nombre... ${ }^{53}$

En principio, no tenemos indicios positivos para suponer que se pueda tratar de Virgilio aquel cuyo nombre Bernhard no es "incapaz" de pronunciar, a menos que recordemos la fórmula de salutación que conforma el título de poemario. Sin embargo, un poco más adelante, podemos leer los siguientes versos, que recuerdan a las palabras de Tiresias en La tierra baldía:

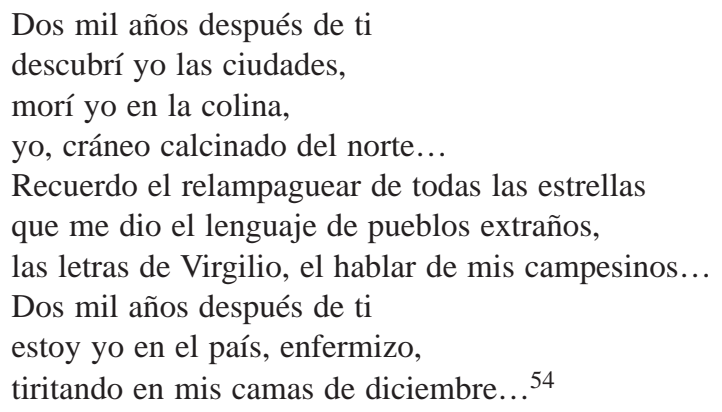

Esta es la referencia explícita más importante que se hace al poeta en todo el poemario ("las letras de Virgilio"), si bien aquí se trata de una referencia en tercera persona y no de una invocación. No obstante, cuando el

\footnotetext{
52 Benhard 1989.

${ }^{53}$ Bernhard 1989, p. 27.

${ }^{54}$ Bernhard 1989, p. 29.
} 
poeta dice "Dos mil años después de ti", nos preguntamos a quién se puede referir si no es al propio Virgilio. La otra referencia explícita, al margen del título, está en el poema titulado "Quién en esta ciudad":

Tú en el camino de los pensamientos...

campos embrutecidos humean

en medio de la perfección.

Conquistadores del mundo:

Dante, Virgilio, Pascal. ${ }^{55}$

La enumeración "Dante, Virgilio, Pascal" deja entrever algunas claves biográficas acerca de la propia formación de Bernhard y de ciertos referentes literarios que también pueden encontrarse en otros pasajes de su obra. Las tres figuras constituyen referentes educativos ineludibles, antiguos y modernos. Dante, entre otras cosas, convirtió a Virgilio en el guía y maestro por antonomasia. Hasta aquí las referencias a Virgilio en el poemario. Pese al título o, quizá por esta misma razón, el vacío virgiliano en la obra se hace palpable. Conviene regresar a otro pasaje del libro antes citado del profesor Von Albrecht, donde volvemos a leer una observación verdaderamente notable:

Virgilio es un maestro de la representación indirecta. En varias églogas el personaje principal está ausente. ${ }^{56}$

La observación, si bien hecha sobre Virgilio, podría ser perfectamente aplicable al moderno poemario que estamos leyendo, pero se vuelve aún más pertinente si vamos a la nota a pie de página que cierra el texto que acabamos de citar:

Un ejemplo rotundo de esta técnica del espacio vacío en época moderna es el profesor muerto en Heldenplatz, en Thomas Bernhard. ${ }^{57}$

Heldenplatz, o La plaza de los héroes, título relativo a un conocido enclave urbano vienés ligado a la moderna historia de Austria, es una polémica obra teatral escrita en el decenio de los años ochenta. Von Albrecht la relaciona ahora con una técnica literaria propia de Virgilio, la de la representación indirecta de un personaje que resulta clave para la obra, si bien está ausente, con una obra dramática moderna sin vinculación alguna. Desde este punto de vista, si repasamos el poemario Ave Virgilio, cabría postularse que

\footnotetext{
55 Bernhard 1989, p. 81.

56 Von Albrecht 2012, p. 89.

${ }^{57}$ Von Albrecht 2012, p. 89, n. 137.
} 
acaso estemos ante una suerte de representación indirecta del poeta Virgilio, cuya ausencia consciente dentro del poemario de Bernhard no obedecería a la casualidad, sino a un acto deliberado de representar la ausencia del maestro muerto hace 2000 años. Como hemos señalado, Bernhard compone este poemario en el decenio de los años sesenta, pero su publicación como libro se lleva a cabo en 1981, el año del bimilenario de la muerte del poeta. Si estuviéramos ante un vacío consciente, la ausencia de Virgilio tendría, por tanto, un significado parecido al intento de utilizar deliberadamente el vacío como material creativo, a la manera de lo que se lleva a cabo en cierta escultura y arquitectura moderna.

\section{LAS TRADUCCIONES}

Una de las versiones más difundidas de la Eneida durante los años setenta y comienzos de los ochenta fue la traducción en prosa a cargo de María del Dulce Nombre Estefanía, publicada en la editorial Bruguera a finales de los años sesenta. ${ }^{58}$ Asimismo, y ya desde la segunda mitad del siglo XIX, circulaba otra traducción en prosa, la de Eugenio de Ochoa, que había pasado a ser una suerte de versión atemporal, alejada ya de su contexto originario. De esta forma, la prosa se había convertido, al menos en España, en la forma normal de leer el gran poema épico de Virgilio. Esta situación vino a cambiarla Agustín García Calvo en su ya citado estudio sobre Virgilio, ${ }^{59}$ pues tal ensayo aportaba versiones rítmicas que han tenido una impronta decisiva en el curso de la traducción del poeta en España. De esta forma, diez años más tarde, aparece en Alianza una interesante versión de la Eneida a cargo de Rafael Fontán Barreiro, dentro de la incipiente colección de clásicos grecolatinos en la serie "Libro de Bolsillo". La versión de Fontán Barreiro permitía leer los versos de la Eneida vertidos a la lengua española sin perder de vista peculiaridades estilísticas propias de la poesía virgiliana. Aquella versión dejaba entrever el ritmo de la obra, y ha resultado una traducción clave para muchos poetas que luego se han inspirado en la Eneida. La introducción a esta versión de la Eneida muestra algunas características reseñables, como aspectos ideológicos afines a Broch, en lo que respecta a la posibilidad de una segunda lectura de la obra, más allá de los propósitos imperiales de Augusto:

Es indiscutible, por último, que en el proemio del libro III de las Geórgicas Virgilio anuncia una futura obra, comparada en sus versos con un templo, que tendrá a

\footnotetext{
58 Virgilio 1968.

${ }^{59}$ García Calvo 1976.
} 
César en el centro y al fondo las gestas troyanas. Y este César al que se refiere con el entusiasmo de los días de Accio, es ya Octaviano. Cuando termina su poema campesino, Virgilio se decide al fin a recoger la propuesta de Mecenas. Era, pues, el año 29, y hemos visto, sin embargo, cómo tres años después nada puede aún ofrecer a Augusto. ¿Qué obstaculizaba el trabajo del poeta? Quizá su intención primera estaba experimentando un cambio y su fina intuición poética le llevaba a desplazar la cámara, colocando al líder en un segundo plano, para que más destacase la tarea colectiva del pueblo romano, "el pueblo latino y los padres de Alba y de la alta Roma las murallas". Ahora bien, los días no eran fáciles, y no es raro pensar que en Virgilio se fuera enfriando el entusiasmo inicial; si a esto añadimos el que su amigo Cornelio Galo se quitó la vida el año 27, acusado de traición hacia la persona de Augusto, ¿no sería posible pensar en un cierto desengaño político del poeta? ${ }^{60}$

Asimismo, cabe señalar necesidades estilísticas que terminaron llevando al traductor hacia una versión que se asemejaba al verso:

Cuando nos propusimos el presente trabajo, intentamos para poner a Virgilio en nuestra lengua el camino de la prosa, que, sin duda, permitía una mayor precisión al traducir. Sin embargo, el coste era demasiado alto, y nuestro texto se alejaba más y más del original virgiliano. Quienes nos precedieron habían emprendido uno y otro camino, y pueden leerse las traducciones en verso de Gregorio Hernández de Velasco (la más antigua en circulación), de A. Espinosa Pólit (excelente) o de A. García Calvo (de la Eneida sólo el libro VI). Pero la mayoría de los traductores lo han sido en prosa, y no desmiente este dato el que en muchas ocasiones se trate de la versión repetida de Eugenio de Ochoa. Y es que en general las traducciones modernas de los poemas de la literatura clásica se han hecho en prosa, abandonando la tendencia inicial de las lenguas europeas.

Decidimos por fin intentar una traducción en verso y vimos con sorpresa hasta qué punto el latín se dejaba meter en los nuevos moldes. Ciertamente se trata de un verso relajado, que no hace sino forzar al traductor a tener muy en cuenta las palabras exactas de Virgilio y el orden en el que aparecen, emulando en parte el ritmo o la cadencia final de los hexámetros latinos; pero es que, como afirma P. Klossowski (traductor de Virgilio para Gallimard), no podemos aplicar nuestra lógica gramatical en la traducción de un poema «donde precisamente la yuxtaposición voluntaria de las palabras (cuyo contraste produce la riqueza sonora y el prestigio de la imagen) constituye la fisionomía de cada verso». ${ }^{61}$

Fruto de este planteamiento es la traducción que mostramos ahora de unos versos ya citados del libro II (254-256):

\footnotetext{
${ }^{60}$ Fontán Barreiro 1986, p. 15.

${ }^{61}$ Fontán Barreiro 1986, pp. 22-23.
} 
Y ya acudía desde Ténedos la falange argiva con las naves formadas entre el silencio amigo de la luna callada,

buscando la conocida playa $[\ldots] .^{62}$

En 1981, se había publicado también en Alianza la versión en prosa de las Bucólicas y las Geórgicas a cargo de Bartolomé Segura Ramos, cuya segunda edición es de 1986, en coincidencia con la publicación de la Eneida en la misma colección. ${ }^{63}$ En esta edición, resulta pertinente que se señale la orientación "neo-alejandrina" que presidirá ambas obras de Virgilio. ${ }^{64}$ Esta característica del alejandrinismo le habría llegado a Virgilio de los poetas anteriores a su generación, los poetae novi, especialmente Catulo, a su vez tan inspirado por poetas griegos del siglo III a.C. como Calímaco. ${ }^{65}$ En esta línea helenizante, Manuel Fernández Galiano llevó a cabo también una versión de las Églogas, esta vez en versión rítmica, dentro de una obra dedicada a recorrer el origen y desarrollo del género bucólico. ${ }^{66}$

Ya en lo que al comienzo del decenio de los noventa respecta, puede verse claramente una doble dicotomía entre las traducciones, bien en prosa o verso, bien antiguas o modernas. Es significativo que la antigua traducción en verso de Gregorio Hernández de Velasco aparezca prologada por Virgilio Bejarano en Planeta el año de $1982,{ }^{67}$ mientras que en 1990 se publica en Cátedra la versión del ecuatoriano Aurelio Espinosa Pólit con un estudio introductorio a cargo de Fernández Corte. ${ }^{68}$

La "Biblioteca Clásica" de la editorial Gredos viene a mostrar significativamente esta dualidad entre el verso y la prosa, al tiempo que las respectivas introducciones a la versión de las Bucólicas y Geórgicas, por un lado, y de la Eneida, por otro, suponen una síntesis de las nuevas ideas sobre Virgilio desarrolladas a lo largo del decenio anterior. En primer lugar, la versión de las Bucólicas, Geórgicas y el Apéndice Virgiliano a cargo de Tomás de la Ascensión Recio García y de Arturo Soler Ruiz ${ }^{69}$ ofrece, según las propias normas de la colección, una versión en prosa, a la que precede la monu-

62 Virgilio 1986, p. 57.

${ }^{63}$ En Buenos Aires es Hugo Bauzá quien publica su versión en verso de las Geórgicas, precedidas por un estudio de cincuenta y una páginas (Virgilio 1989). Conocimos esta versión, por cierto, gracias a que en el despacho que Agustín García Calvo ocupaba en la Facultad de Filología de la Universidad Complutense había un ejemplar, regalo del traductor.

64 Segura Ramos también preparó una versión en prosa de la Eneida para el Círculo de Lectores (Virgilio 1980).

65 Segura Ramos 1981, p. 7.

${ }^{66}$ Fernández Galiano 1984.

${ }^{67}$ Virgilio 1982.

68 Virgilio 1990a.

${ }^{69}$ Virgilio 1990b. 
mental "Introducción general" a Virgilio de José Luis Vidal Pérez. ${ }^{70}$ Por su parte, la versión póstuma de la Eneida a cargo de Echave-Sustaeta, ${ }^{71}$ con introducción de Vicente Cristóbal, constituye una curiosa excepción, pues está traducida en verso, hecho que motiva una nota aclaratoria de la propia editorial. Al igual que hemos hecho con la versión de Fontán Barreiro, ofrecemos la traducción de los versos 254-256 del libro segundo de la Eneida:

Ya la falange argiva desde Ténedos en formación las naves avanzaba Entre el silencio amigo de la velada luna, proa a la conocida ribera. ${ }^{72}$

La introducción de Vicente Cristóbal para esta obra incorpora en su parte final comentarios sobre Broch y recoge algunos versos del poema de Antonio Colinas (1982). Se trata, en este sentido, de una obra que cierra y resume el período estudiado.

\section{El relato visual. La Eneida de Carlos Franco (1988)9}

Durante los años ochenta, la ilustración gráfica adquiere un sentido propio en lo que respecta, entre otras cosas, a temas clásicos. ${ }^{73}$ En el caso de Virgilio, ${ }^{74}$ tenemos unas Geórgicas ilustradas con aguafuertes por Gerardo Aparicio a partir del verso suelto de Ramón de Síscar, ${ }^{75}$ la Eneida, ilustrada también con aguafuertes por Carlos Franco a partir del texto de Gregorio Hernández de Velasco, ${ }^{76}$ y el catálogo de la exposición que en torno a la

${ }^{70}$ Vidal 1990.

${ }^{71}$ Virgilio 1992.

72 Virgilio 1992, p. 181.

73 Aguilar Moreno 2005.

${ }^{74}$ Para el caso de la Odisea de Homero y las Metamorfosis de Ovidio resulta imprescindible la referencia a Guillermo Pérez Villalta.

75 Virgilio 1983. “Las Geórgicas de P. Virgilio Marón está compuesto por los grabados de Gerardo Aparicio y los versos del poeta griego traducidos por Ramón de Síscar y de Montoliú. Es la primera edición realizada desde Madrid bajo el nombre de Antonio Machón Editor. Esta obra se presenta en dos tomos de 20.5 x $15 \mathrm{~cm}$ impresos y estampados en papel de hilo Velín de Arches de 160 gramos en un total de 120 páginas por tomo. Compuesto a mano, en tipos móviles Bodoni de cuerpo 12. Cada tomo va ilustrado con nueve grabados y una viñeta en portada realizados con las técnicas de aguafuerte, aguatinta y punta seca, estampados a mano en tórculo por el sistema tradicional. Uno de los grabados se presenta exento, firmado y numerado correlativamente con el libro; los ocho restantes incorporados al texto. Respecto a la encuadernación, el tomo se presenta en estuche; cosido a mano con cubiertas de papel artesanal gofrado" (Aguilar Moreno 2005, p. 194).

76 Virgilio 1988. "La Eneida de Publio Virgilio Marón, en versión del Doctor Gregorio Hernández de Velasco (1555) está ilustrada con veinticuatro aguafuertes originales de Carlos Franco. Los textos son compuestos a mano sobre papel Ingres Fabriano por Julio Soto. La encuadernación corre a cargo de Carlos Vera, realizada a mano en piel de cabra con hierro de lomo 
propia Eneida organizó este mismo artista. ${ }^{77}$ Vamos a centrarnos en Carlos Franco, cuyo interés por la recreación de los antiguos mitos ya ha sido objeto de un estudio previo. ${ }^{78} \mathrm{El}$ hecho de que la motivación inicial del artista por la Eneida viniera de un encargo editorial ha dado lugar a que las composiciones tengan una clara relación con ciertos pasajes, fruto de una atenta lectura. Esta motivación textual es evidente en las ilustraciones que aparecen en la edición de la Eneida, pero también resulta evidente en las composiciones llevadas a cabo para la exposición, si bien éstas últimas se muestran más autónomas con respecto al texto de origen. Conviene prestar un poco de atención a ambos documentos: la traducción y el catálogo.

El volumen de la traducción ${ }^{79}$ no tiene prólogo ni introducción, aunque sí aparece un colofón que ofrece los datos de la tirada. Los aguafuertes, a razón de dos por cada libro, no cuentan tampoco con texto alguno que explique su motivación, pero es relativamente sencillo encontrar su referente textual en la página enfrentada a él.

El catálogo de la exposición sobre La Eneida ${ }^{80}$ por su parte, muestra una mayor libertad temática. Aunque Carlos Franco se sigue inspirando mayormente en el poema épico de Virgilio, ya no lo hace como mero ilustrador. Por ello, ahora se ayuda de pequeños títulos que contextualicen la obra gráfica. Sin embargo, las referencias textuales concretas siguen haciéndose evidentes. La gran diferencia estriba, sin duda, en que ahora el artista elige una serie de motivos y personajes de manera específica, como si estuviera desmontando el gran relato épico para construir nuevos microrrelatos a partir de la propia Eneida. En el diario El País (19 de noviembre de 1988) apareció una interesante reseña sobre la exposición a cargo de Francisco Calvo Serraller, que aparece en la siguiente página. ${ }^{81}$

De la reseña podemos colegir cómo Carlos Franco ha utilizado lenguajes artísticos propios de la modernidad (Picasso, Kokoschka, Alfred Kubin, sin olvidar a los fundamentales Velázquez y Goya) para llevar a cabo su recreación ilustrada de la Eneida. Dado que en su exposición Carlos Franco se mostró mucho más libre a la hora de elegir los temas, se permite hacer

estampado en oro fino. La estampación de los grabados se realizó sobre papel Velín de Arches en los talleres de Mitsuo Miura de Madrid. / La edición de la tirada consta de ciento treinta y nueve ejemplares. Consta de una edición especial numerada del 1 al 35, llevan fuera de texto dos grabados especialmente hechos para esta edición. Aguafuertes y aguatintas de diferentes formatos ilustran los doce libros de La Eneida" (Aguilar Moreno 2005, p. 177). Consulta del volumen en la BNE el día 14 de mayo de 2018 (Biblioteca Nacional de España [sign. 9/30325] edición facsimilar).

77 Franco 1988.

78 Blázquez 2007.

79 Virgilio 1988.

${ }^{80}$ Franco 1988.

${ }^{81}$ Calvo Serraller 1988. 


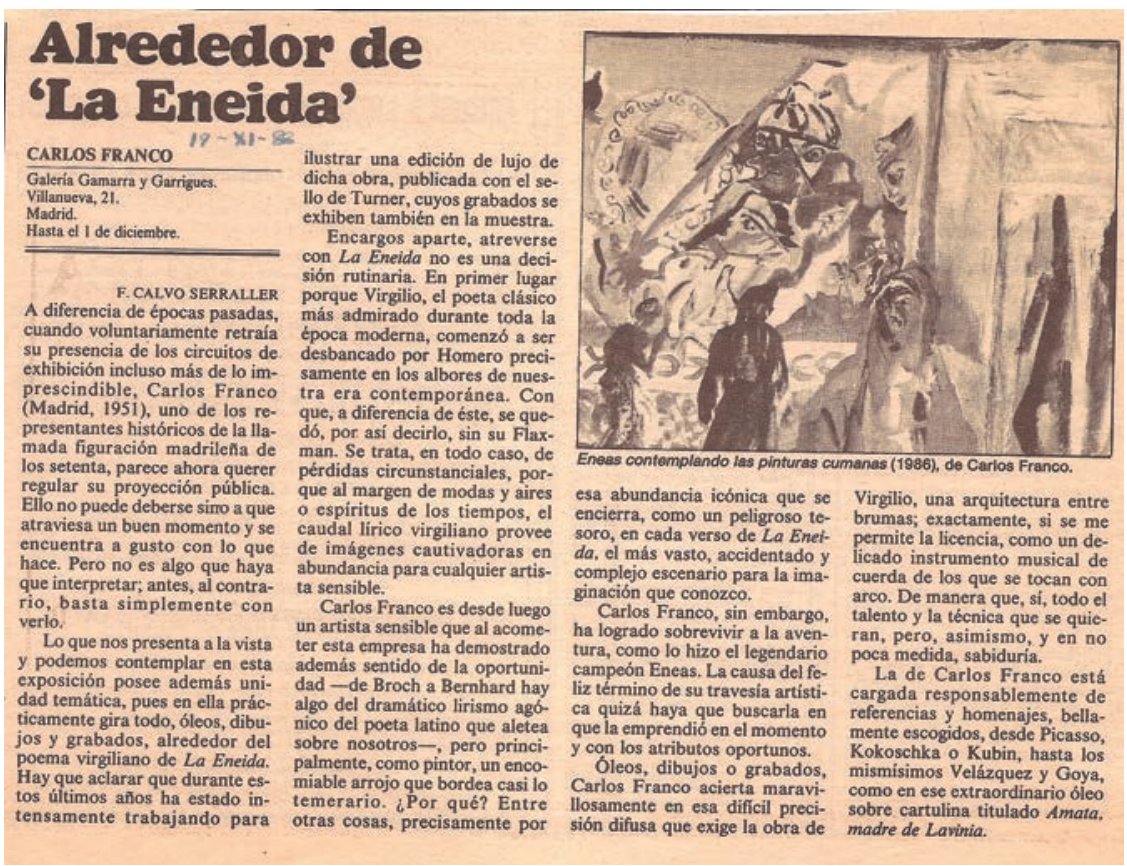

Reseña de Francisco Calvo Serraller, publicada en el suplemento de Artes del diario El País (19 de noviembre de 1988), dedicada a la exposición sobre la Eneida del pintor Carlos Franco.

variaciones acerca de un mismo motivo. El catálogo comienza con una "Introducción" a cargo de Ángel González García que va encabezada por el sugerente título "Sub luce maligna", expresión que pertenece al conocido pasaje de la bajada al infierno:

Ibant obscuri sola sub nocte per umbram perque domos Ditis uacuas et inania regna: quale per incertam lunam sub luce maligna est iter in siluis, ubi caelum condidit umbra Iuppiter, et rebus nox abstulit atra colorem. ${ }^{82}$

Iban oscuros bajo la noche solitaria, por entre la sombra y las vacías mansiones de Plutón, sus desolados reinos, igual que entre luna incierta, bajo luz maligna, se camina en el bosque, cuando Júpiter cubre de sombra el cielo y la negra noche priva de color a las cosas. ${ }^{83}$

${ }^{82}$ Verg., Aen., VI, 268-272.

83 Trad. García Jurado. 
Esta "luz maligna", propia del infierno al que desciende Eneas con la Sibila, es comparada con la luz del cuadro de Ingres donde Augusto, ante la mirada despectiva de Livia, sostiene a Octavia, dado que ésta se ha desmayado al escuchar el nombre de su hijo Marcelo, evocado en un verso del libro VI de la Eneida que está recitando Virgilio, aunque no aparece en el cuadro. Más allá de las diferencias estéticas de este cuadro de Ingres con respecto a la obra de Carlos Franco, cabe destacar el hecho común de remitirse a los versos 882-886 del libro VI de la Eneida: tu Marcellus eris. Dentro del prólogo del catálogo, la Eneida es considerada de manera significativa como un cúmulo de sensaciones (sucesión, maraña, madeja, órgano). Si comparamos estas composiciones con las ilustraciones destinadas a la traducción de la Eneida, cabe señalar tanto los motivos comunes como los divergentes. Hay motivos recurrentes (alegría, irracionalidad, sexo, crueldad...), así como la "textualidad" de algunas imágenes, muy cercanas a ciertos versos de la obra. Este conjunto de composiciones sobre la obra literaria nos permite observar cómo, más allá de la mera ilustración, estamos ante una verdadera relectura visual donde, no obstante, cabe encontrar rasgos textuales concretos. Veamos el ejemplo significativo de la composición titulada "Eneas contemplando las pinturas cumanas". Cabe preguntarse, en principio, si, al referirse a las "pinturas cumanas", Carlos Franco está pensando las representaciones cinceladas por Dédalo en el templo de Cumas. Si estamos en lo cierto, la pintura de Carlos Franco se estaría refiriendo de manera muy concreta a unos versos del libro sexto de la Eneida, justamente el momento en que Acates ha regresado con la sacerdotisa Deífobe para avisar a Eneas, extasiado ante la obra de Dédalo, de que deben ponerse manos a la obra con los ritos pertinentes para poder ingresar en los infiernos. Se trata de un pequeño texto ecfrástico donde el poeta no sólo describe lo que aparece cincelado en la obra de Dédalo, sino lo que habría podido seguir cincelando sobre el oro (la caída de su hijo Ícaro), en caso de que el dolor no hubiera hecho al padre deponer sus manos:

\section{[...] Tu quoque magnam}

partem opere in tanto, sineret dolor, Icare, haberes.

Bis conatus erat casus effingere in auro,

bis patriae cecidere manus. Quin protinus omnia

perlegeret oculis, ni iam praemissus Achates

adforet atque una Phoebi Triviaeque sacerdos,

Deiphobe Glauci, fatur quae talia regi. ${ }^{84}$

${ }^{84}$ Verg., Aen., VI, 33-36. 


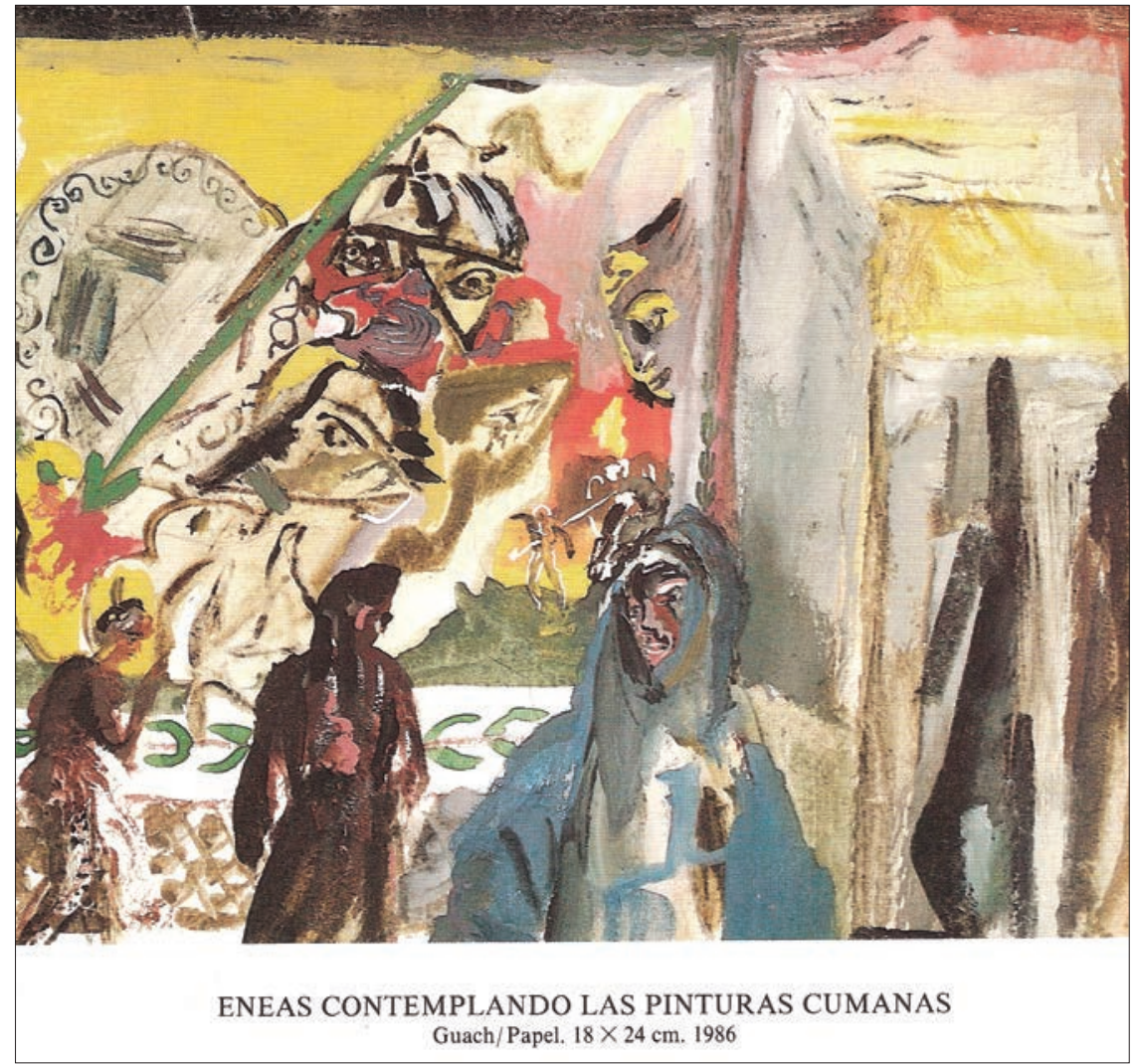

Página del catálogo de la exposición sobre la Eneida a cargo de Carlos Franco, donde aparece la ilustración de Eneas mientras contempla las pinturas cumanas.

Este "guach" (gouache) sobre papel es muy interesante, pues, a pesar de su clarísima referencia a unos versos de la Eneida, muestra una aparente incongruencia. En principio, si acudimos al pasaje original donde se inspira, no tendremos dificultades en comprobar que se refiere a la obra que Dédalo cinceló sobre oro, y en la que no pudo incluir la muerte de su propio hijo, Dédalo. ${ }^{85}$ El sentido está claro si analizamos la expresión effingere auro, que no sería otra cosa que "cincelar en oro". Cabría pensar que el pintor se ha concedido una licencia, de forma que representa como pintura lo que en la Eneida son relieves. Pero no olvidemos que Carlos Franco ha ilustrado una determinada traducción de Virgilio, la de Gregorio Hernández de Velasco, que vierte de la siguiente forma el pasaje:

${ }^{85}$ Bis conatus erat casus effingere auro / bis patriae cecidere manus; Verg., Aen., VI, 32-33. 


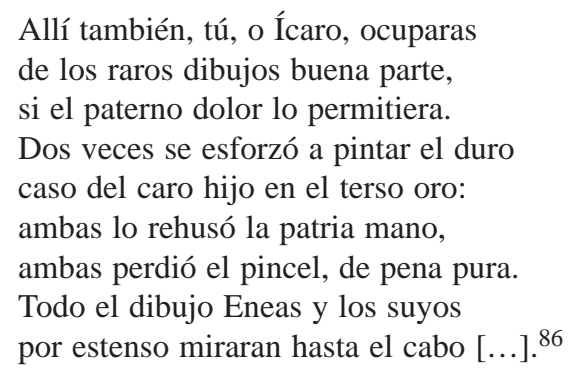

De esta forma, Carlos Franco está siguiendo el texto de Hernández de Velasco, quien ha convertido admirablemente la obra de Dédalo en una pintura sobre el "terso oro".

\section{CONCLuSiones}

Ya nos planteábamos al comienzo de este ensayo académico que, probablemente, más de una persona interesada se preguntaría acerca de la relación habida entre los años ochenta del siglo xx y la intemporal figura de Virgilio. Precisamente esto es lo que hemos intentado mostrar a lo largo de estas páginas, es decir, cómo a pesar de su estela milenaria, Virgilio también está sujeto a la historicidad de cada momento. De esta forma, especialmente como poeta moribundo, enfermo o neo-alejandrino, el Virgilio que recibimos la generación formada durante los años ochenta del siglo xx presenta unas características propias que no tienen por qué ser estrictamente sincrónicas, pues algunas, como la impronta de Broch o el libro de García Calvo, provienen ya de antes de los ochenta, mientras otras, como el uso de ciertas imágenes virgilianas por parte de Borges, calará mucho más en los poetas de los años noventa. En cualquier caso, tal como se ha mostrado a lo largo de este trabajo, los documentos estudiados permiten establecer seis aspectos fundamentales que resumimos a continuación:

- La idea del poeta moribundo, gracias a la novela de Broch.

- La enfermedad de la poesía en el ensayo de García Calvo.

- La celebración del bimilenario de la muerte de Virgilio, de la que sabemos por las reseñas periodísticas (L. A. de Villena apunta tácitamente a García Calvo en su semblanza virgiliana) y, sobre todo, por el poema de Colinas (quien apunta tácitamente a Broch).

- El uso de las imágenes virgilianas en la poesía de Borges (cuya impronta en los poetas españoles no se deja ver hasta el decenio de los noventa)

\footnotetext{
${ }^{86}$ Hernández de Velasco apud Caruso 2016, p. 123, vv. 61-69.
} 
y la ausencia consciente de Virgilio en la poesía Bernhard (cuya poesía tiene mucho de T. S. Eliot).

- El regreso a la traducción rítmica (Fontán Barreiro lleva a cabo una de las versiones más leídas)

- La relectura visual (Carlos Franco acomete una viva iconografía)

El Virgilio de los años ochenta ofrece, pues, unas características propias que lo definen frente a otras visiones posibles a lo largo del siglo xx. Puede que sea una de las más singulares.

\section{BIBLIOGRAFÍA}

Fuentes antiguas

Virgilio, Eneida, trad. María del Dulce Nombre Estefanía, Barcelona, Bruguera, 1968.

Virgilio, Eneida, trad. Bartolomé Segura Ramos, Barcelona, Círculo de Lectores, 1980.

Virgilio, Eneida, trad. Gregorio Hernández de Velasco, Barcelona, Planeta, 1982.

Virgilio, Las Geórgicas en verso suelto castellano por Ramón de Síscar y de Montoliú; grabados de Gerardo Aparicio, Madrid, A. Machón, 1983.

VIRGILIO, Eneida, intro. y trad. Rafael Fontán Barreiro, Madrid, Alianza, 1986.

VIRGILIO, La Eneida, Madrid, Turner, 1988.

Virgilio, Las Geórgicas, est. y trad. Hugo Bauzá, Buenos Aires, eudebA, 1989.

Virgilio, Eneida, trad. Aurelio Espinosa Pólit, Madrid, Cátedra, 1990a.

Virgilio, Bucólicas, Geórgicas, Apéndice Virgiliano, introd. gral. J. L. Vidal, trad. Tomás de la Ascensión Recio García y Arturo Soler, Madrid, Gredos, 1990b.

VIRGILIO, Eneida, introd. Vicente Cristóbal, trad. Javier Echave-Sustaeta, Madrid, Gredos, 1992.

\section{Fuentes modernas}

Aguilar Moreno, Marta, "El grabado en las ediciones de bibliofilia realizadas en

Madrid entre 1960-1990", tesis doctoral, Madrid, Universidad Complutense de Madrid, 2008, http://biblioteca.ucm.es/tesis/bba/ucm-t28495.pdf (16/11/2020).

ArbeA, Antonio, "Virgilio según Juan Pablo II", Onomazein, 8, 2003, pp. 233-245.

BauzÁ, Hugo F., Virgilio en el bimilenario de su muerte, Buenos Aires, Parthenope, 1982.

BAuZÁ, Hugo F., Virgilio, memorias del poeta. Una autobiografía espiritual, Buenos Aires, Biblos, 2011.

Benhard, Thomas, Ave Virgilio, versión Miguel Sáenz, Barcelona, Ediciones Península, 1988. 
Biblioteca Apostólica Vaticana, Virgilio illustrato nel libro (secc. IV-XIX). Esposizione organizzata in occasione del Bimillenario Virgiliano. Itinerario. Citta' del Vaticano, Biblioteca Apostólica Vaticana, Agosto de 1981.

Blázquez, José María, "Mitos clásicos y naturaleza en la pintura y dibujos de Carlos Franco", en María José Castillo Pascual (coord.), Congreso Internacional "Imagines", La Antigüedad en las artes escénicas y visuales / International Conference "Imagines", The reception of Antiquity in performing and visual Arts (Logroño, Universidad de La Rioja, Logroño, 22-24 de octubre de 2007), Logroño, Universidad de La Rioja, 2008, pp. 529-548.

Borges, Jorge Luis, La cifra, Madrid, Alianza, 1981.

Borges, Jorge Luis, Los conjurados, Madrid, Alianza, 1985.

Borges, Jorge Luis, Obras Completas IV, Buenos Aires, Emecé, 1996.

Broch, Hermann, La muerte de Virgilio, trad. Arístides Gregori, Buenos Aires, Editorial Jacobo Peuser, 1946.

Broch, Hermann, La muerte de Virgilio, vers. J. M. Ripalda sobre trad. Arístides Gregori, Madrid, Alianza Tres, 1979.

Calvo Serraller, Francisco, "Alrededor de La Eneida", El País, 19 de noviembre de 1988.

CARDucci, Giosuè, Rime nuove, Bologna, Zanichelli, 1887.

Caruso, Massimo, "La primera traducción impresa completa de la Eneida de Virgilio realizada por Gregorio Hernández de Velasco", tesis doctoral, Padua, Università degli Studi di Padova, 2016, http://paduaresearch.cab.unipd.it/9398/1/ caruso_phd.pdf.

Colinas, Antonio, "Lección primera y última de Virgilio", Ínsula: Revista de Letras y Ciencias Humanas, 1981, 418, pp. 1 y 5 (publicado luego en Colinas 1989).

Colinas, Antonio, Noche más allá de la noche, Madrid, Visor, 1982.

Colinas, Antonio, El sentido primero de la palabra poética, México/Madrid [etc.], Fondo de Cultura Económica, 1989.

Colinas, Antonio, Poética y Poesía, Madrid, Fundación Juan March, 2004.

Conte, Gian Carlo, The Poetry of Pathos, Oxford, Oxford University Press, 2007, http://dx.doi.org/10.1093/acprof:oso/9780199287017.001.0001.

CRISTóbal, Vicente, "Introducción" a Virgilio, Eneida, Madrid, Gredos, 1992, pp. 11-130.

D’Ors, Miguel, "Sobre las construcciones del tipo «lento en la sombra» en la obra de Jorge Luis Borges", Anales de Literatura Hispanoamericana, 5, 1976, pp. 379-386.

DonKer, Marjorie, "The Waste Land and the Aeneid", pmla, 89/1, 1974, pp. 164173, http://dx.doi.org/10.2307/461679.

Fernández Galiano, Manuel, Títiro y Melibeo: la poesía pastoril grecolatina, Madrid, Fundación Pastor de Estudios Clásicos, 1984.

FontÁn BARREIRo, Rafael, "Introducción" a Virgilio, Eneida, Madrid, Alianza, 1986, pp. 7-24.

Franco, Carlos, La Eneida. Noviembre 1988, Madrid, Gamarra y Garrigues, 1988.

García Calvo, Agustín, Virgilio, Madrid, Júcar, 1976.

García JuRAdo, Francisco, "Todas las cosas que merecen lágrimas. Borges, traductor de Virgilio", Studi Ispanici, 35, 2010, pp. 291-309. 
García Jurado, Francisco, Virgilio. Vida, mito e historia, Madrid, Síntesis, 2018.

GAYNOR, Grace, “'Cualquier hombre es todos los hombres' ('any man is all men'): Jorge Luis Borges, W. B. Yeats and Eternal Return”, Working Papers in the Humanities, vol. 11, 2017, pp. 9-16, http://www.mhra.org.uk/pdf/wph-11-2.pdf

Gimferrer, Pere, "El escritor de hoy y el mundo clásico. Discurso inaugural del Congreso Español de Estudios Clásicos. Madrid. 1987”, en Noche en el Ritz, Barcelona, Anagrama, 1996, pp. 144-159 (publicado inicialmente en Actas del VII Congreso Español de Estudios Clásicos, vol. 1, Madrid, SEEC, 1989, pp. 9-20).

González Iglesias, Juan Antonio, Esto es mi cuerpo, Madrid, Visor, 1997.

HAECKER, Theodor, Virgilio, padre de Occidente, Madrid, EPESA, 1945.

Haro Tecglen, Eduardo, "Sobra Eurípides”, El País, 28 de abril, 1987, http://www. elpaís.com/diario/1987/04/28/cultura/546559209_850215.

Herreros Tabernero, Helena, "El libro I de las Geórgicas en la literatura española", Cuadernos de Filología Clásica. Estudios Latinos, 27/1, 2007, pp. 47-77.

Huerta Calvo, Javier, "Comentario de un poema de Antonio Colinas (Noche más allá de la noche. Canto X)", en AA. Vv., El viaje hacia dentro (La poesía de Antonio Colinas), Madrid, Calambur, 1997, pp. 211-228.

J.A.P.M., "No hay influencia directa de la obra de Virgilio en la poesía española", $A B C, 28$ de marzo de 1981.

López López, Matías, “Agustín García Calvo, filólogo clásico”, Minerva, 26, 2013, pp. 301-315.

LyOTARD, Jean-François, La condición postmoderna. Informe sobre el saber, Barcelona, Planeta-Agostini, 1993.

Magrelli, Valerio, "Presentazione", en Thomas Bernhard, Ave Virgilio. Carme, Milano, Ugo Guarda Editore, 2017.

Mariscal de Gante Centeno, Carlos, "La poética de la hipálage virgiliana en la poesía moderna: Aurelio Espinosa Pólit, Jorge Luis Borges y José Emilio Pacheco", Literatura: Teoría, Historia, Crítica, 22, 2020, pp. 71-109, http:// dx.doi.org/10.15446/lthc.v22n1.82293.

Nogales-Baena, José L., "En torno al prólogo de Borges a la Eneida", 1616, 7, 2017, pp. 245-258.

Oroz Reta, José, "Virgilio en España: ecos del Bimilenario", Helmantica: Revista de Filología Clásica y Hebrea, 33, 101-102, 1982, pp. 571-579, http://dx.doi. org/10.36576/summa.3080 (Ejemplar dedicado a: Bimilenario de Virgilio. Simposio internacional. Salamanca, 16 - 18 de marzo, 1982), http://summa.upsa.es/ high.raw id $=0000003080 \&$ name $=00000001$. original.pdf.

Tusón, Vicente y Lázaro CARreter, Literatura española cou, Madrid, Anaya, 1993. V Aтtimo, Gianni, Introducción a Nietzsche, Barcelona, Península, 2001.

VIDAL, José Luis, "Introducción” a Virgilio, Bucólicas, Geórgicas, Apéndice Virgiliano, Madrid, Gredos, 1990b, pp. 7-146.

Vidal, José Luis, "Por qué Virgilio quería quemar la Eneida..., si es que quería", en Humanitas in honorem Antonio Fontán, Madrid, Gredos, 1992, pp. 479-484.

Villena, Luis Antonio de, Catulo, Madrid, Júcar, 1979.

Villena, Luis Antonio de, "Conmemoración de Virgilio en el bimilenario de su muerte" y "Símbolo de una cultura libre, humana y gozosa", El País, 28 de marzo de 1981. 
"Virgilio: conmemoración del bimilenario del gran poeta latino", $A B C, 21$ de marzo de 1981.

Von Albrecht, M., Virgilio: Bucólicas, Geórgicas, Eneida. Una introducción, Murcia, Universidad de Murcia, 2012.

$$
* * *
$$

Francisco García JuRAdo es doctor en Filología Clásica por la Universidad Autónoma de Madrid (UAM) y actualmente es catedrático de Filología Latina en la Universidad Complutense de Madrid (UCM). Tiene publicados más de 200 artículos académicos y más de 20 libros acerca de sus ámbitos de investigación, que son la Semántica del latín, la Historiografía de la Literatura Clásica y la Teoría de la Tradición y la Recepción Clásica. Entre sus principales trabajos destaca su Introducción a la Semántica Latina (Madrid, Servicio de Publicaciones de la Universidad Complutense, 2003), El arte de leer. Antología de la Literatura Latina en los autores del siglo XX (Madrid, Liceus, 2005 y segunda edición revisada en 2007), Borges, autor de la Eneida (Madrid, ELR, 2006), Marcel Schwob, antiguos imaginarios (Madrid, ELR, 2008), Teoría de la Tradición Clásica (México, unAm, 2016) y Catálogo Razonado de Manuales Hispanos de Literatura Clásica (1872-1935) (CRMHLC) (Madrid, Guillermo Escolar, 2018). Es, asimismo, investigador principal del proyecto de investigación "Diccionario Hispánico de la Tradición Clásica (DHTC)". 